Review

\title{
Benthic microalgal production in the Arctic: applied methods and status of the current database
}

\author{
Ronnie N. Glud ${ }^{1,2, *}$, Jana Woelfel ${ }^{3}$, Ulf Karsten ${ }^{3}$, \\ Michael Kühl' ${ }^{2}$ and Søren Rysgaard ${ }^{4}$ \\ ${ }^{1}$ Dustaffnage Marine Laboratory, Scottish Association \\ of Marine Sciences, Oban, Scotland PA37 1QA, UK, \\ e-mail: Ronnie.Glud@sams.ac.uk \\ 2 Marine Biological Laboratory, Department of Biology, \\ University of Copenhagen, Strandpromenaden 5, \\ 3000 Helsingør, Denmark \\ ${ }^{3}$ Institute of Biological Sciences, Applied Ecology, \\ University of Rostock, Albert-Einstein-Str 3, 18051 \\ Rostock, Germany \\ ${ }^{4}$ Greenland Institute of Natural Resources, Box 570, \\ 3900 Nuuk, Greenland \\ * Corresponding author
}

\begin{abstract}
The current database on benthic microalgal production in Arctic waters comprises 10 peer-reviewed and three unpublished studies. Here, we compile and discuss these datasets, along with the applied measurement approaches used. The latter is essential for robust comparative analysis and to clarify the often very confusing terminology in the existing literature. Our compilation demonstrates that i) benthic microalgae contribute significantly to coastal ecosystem production in the Arctic, and ii) benthic microalgal production on average exceeds pelagic productivity by a factor of 1.5 for water depths down to $30 \mathrm{~m}$. We have established relationships between irradiance, water depth and benthic microalgal productivity that can be used to extrapolate results from quantitative experimental studies to the entire Arctic region. Two different approaches estimated that current benthic microalgal production in the Arctic is between 1.1 and $1.6 \times 10^{7}$ tons $C$ year ${ }^{-1}$. Climate change is expected to increase the overall primary production and affect the balance between pelagic and benthic productivity in the Arctic. It is therefore imperative to get better quantitative understanding of the relationship between increased freshwater run-off, shrinking sea-ice cover, light availability and benthic primary production to assess future impact on the Arctic food web and trophic coupling.
\end{abstract}

Keywords: Arctic; benthic microalgae; benthic primary production; photosynthesis.

\section{Introduction}

The Arctic oceans, including all marine water bodies at latitudes above the Arctic Circle, cover $>20 \times 10^{6} \mathrm{~km}^{2}$ and encompass $\sim 25 \%$ of the global coastal region (areas with water depths <200 m) (Menard and Smith 1966, Jakobsson et al. 2008). The Arctic coastal regions cover $\sim 5.8-6.1 \times 10^{6} \mathrm{~km}^{2}$ with an average water depth of $80 \mathrm{~m}$ (Gattuso et al. 2006, Jakobsson et al. 2008) and a significant fraction of this area can be expected to accommodate benthic primary production. Gattuso et al. (2006) estimated that on average, $25 \%$ of the Arctic coastal seabed receives $>1 \%$ of the surface down welling irradiance during the five summer months, with a much larger fraction expected to occasionally experience irradiances of this magnitude.

An increasing number of studies suggest that benthic microalgae contribute significantly to subtidal coastal ecosystem production (Charpy-Roubaud and Sournia 1990, Meyercordt et al. 1999, Nelson et al. 1999, Jahnke et al. 2000, Jahnke 2005, Glud et al. 2008). Furthermore, studies from lower latitudes have documented the importance of benthic microphytes for supporting shallow water food-webs (e.g., Middelburg et al. 2000). In an extensive review of 85 studies, Cahoon (1999) concluded that previous estimates on benthic microalgal productivity had markedly underestimated their importance for marine ecosystem production - especially in oligotrophic systems. Overall, this author provided an annual global estimate of $5 \times 10^{8}$ tons $C$ for the neritic microalgal primary production. Cahoon (op. cit.) also showed that, whereas some areas were relatively well studied (i.e., temperate intertidal and eutrophicated systems), others were grossly under-sampled, especially the Arctic region for which at that time there were only two studies! The polar coastal areas differ from the better studied temperate regions in being exposed to ice-cover and darkness during extensive periods of the year. Furthermore, they are pristine and experience relatively low temperatures. The seabed is often exposed to ice-mediated erosion and erratic, massive inputs of erosion material during spring (Rachold et al. 2004, Zacher et al. 2009). Therefore, findings from lower latitude systems cannot be extrapolated a priori to polar ecosystems.

Camera-based mapping of the sea-bed over larger areas in the Arctic often shows an extensive and dense cover of microalgae that is intensively grazed by macrofauna (Figure 1). One striking observation provided by such photo documentation is the pronounced smallscale patchiness, which must be accounted for when evaluating data on benthic productivity. Closer inspection of sea-bed samples shows that the microalgal cover is often dominated by pennate diatoms and in some cases dinoflagellates or Cyanobacteria; the first group appears to dominate Arctic microphytobenthos (Vetrov and Romankevich 2004 and references therein). In the follow- 

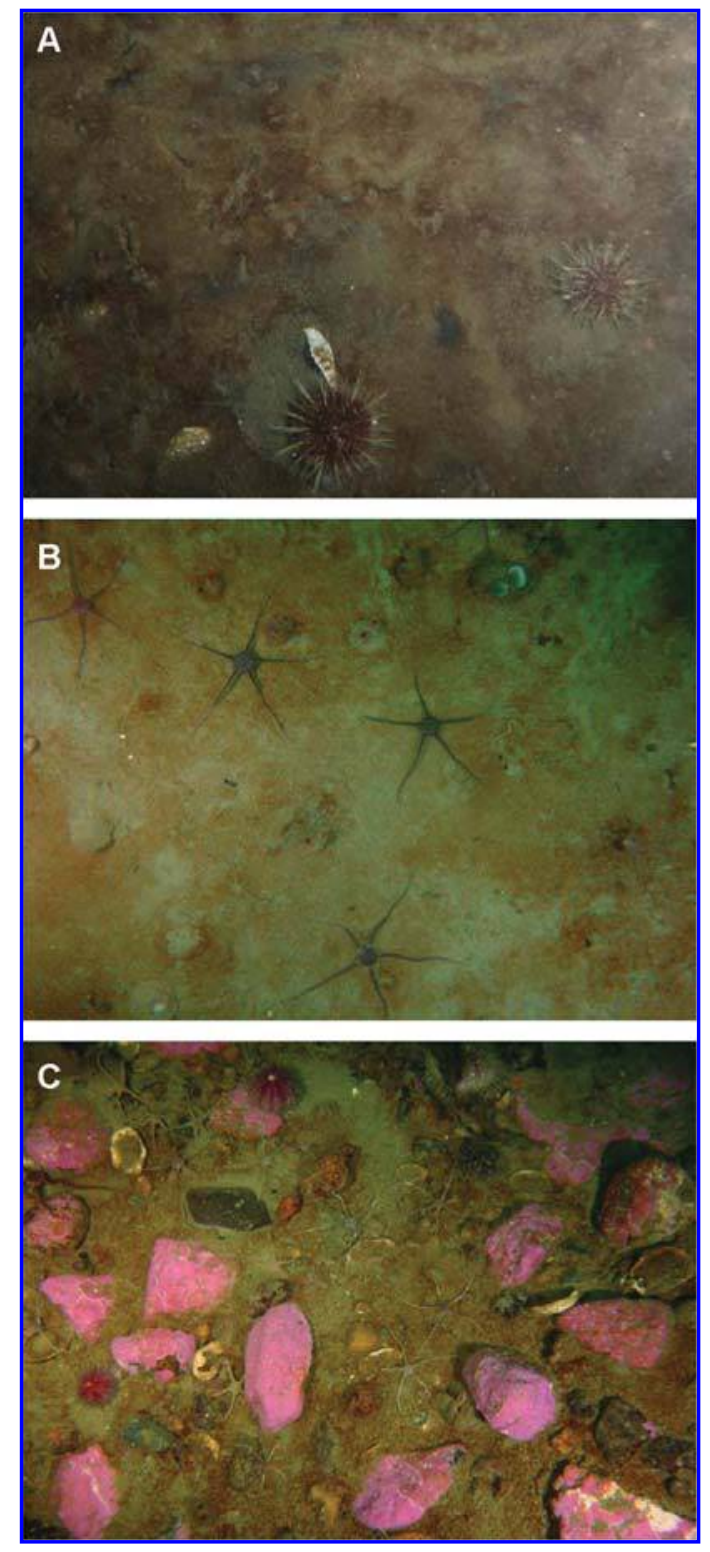

Figure 1 In situ photographs of benthic microalgal coverage. (A) in NW Greenland $\left(72^{\prime} 22.53^{\prime \prime} N, 55^{\prime} 33.37^{\prime \prime} \mathrm{W}\right)$ at $18 \mathrm{~m}$ of water depth; (B) in NE Greenland (74'18.59" N, 20'14.48" W) in 20 m water depth and $(C)$ in NE Greenland ( $74^{\prime} 18.59^{\prime \prime} \mathrm{N}, 20^{\prime} 14.74^{\prime \prime}$ W) in $30 \mathrm{~m}$ water depth. In all cases the brown patches indicate the presence of pennate diatoms (the lower panel is dominated by the occurrence of stones covered with coralline red algae). Each image covers an area of $40 \times 30 \mathrm{~cm}$.

Photograph made available by P.B. Christensen, M. Sejr, and P. Batty and reproduced by kind permission of the owners.

ing, we have compiled and discuss here the available database on benthic microalgal production from the Arctic. In total we have identified 10 peer-reviewed and three unpublished studies of shelf areas off Siberia, Svalbard, Greenland and North America (Figure 2). We identified a few more abstracts and book-chapters that assess the benthic productivity in Arctic systems, but in these cases methodology and calculation procedures were often difficult to evaluate. The overall aim of this review is to assess and evaluate the importance of benthic microphytes for primary production in the Arctic coastal region. However, as the current database has been obtained using different measuring approaches that can be confounded by other benthic processes and may express net or gross photosynthesis to differing degrees, it is important to thoroughly evaluate each when compiling the available data.

\section{Applied methods and the current database on Arctic microphytobenthic activity}

Most assessments of benthic microalgal productivity are based on core or chamber incubations following the autotrophic incorporation of added $\mathrm{H}^{14} \mathrm{CO}_{3}{ }^{-}$or the total exchange of $\mathrm{O}_{2}$ and/or dissolved inorganic carbon (DIC). However, in recent years alternative procedures like $\mathrm{O}_{2}$ microsensor measurements, and pulse amplitude modulation (PAM) fluorometry (Barranguet and Kromkamp 2000, Kühl et al. 2001, Glud et al. 2002), have been introduced to complement these well-established techniques. The approaches target different steps in the conversion of light energy to organic material and are to a varying extent confounded by the concurrent respiration that takes place within natural benthic communities. The different measuring approaches are, therefore, complementary, but unfortunately most studies have only applied one approach and, as discussed below it is not always straightforward to convert results obtained by one approach to those of another. Furthermore, different approaches define net and gross primary production differently and procedures for extrapolating measurements to in situ light levels on daily or seasonal time scales are different. To complicate matters, most published studies do not have sufficient information to recalculate measurements to a standardized procedure. Consequently, evaluating the importance of benthic microalgal photosynthesis on the basis of the existing database requires a certain degree of "creativity" and a clearly defined terminology. Below, we discuss the respective measuring procedures applied to assess the activity of intact benthic microalgal communities and we define the terminology applied in the rest of the manuscript, all with the overall aim of comparing, compiling and extrapolating the presently available Arctic database.

\section{Benthic $\mathrm{H}^{14} \mathrm{CO}_{3}{ }^{-}$incubation procedures}

Early studies on microbenthic production mostly applied the ${ }^{14} \mathrm{C}$-incubation technique that had been successfully developed to study productivity of planktonic communities (Steenman-Nielsen 1952). In essence, $\mathrm{H}^{14} \mathrm{CO}_{3}^{-}$is added to benthic chambers placed directly on the seabed or to collected sediment cores exposed to a controlled irradiance in the laboratory (Colijn and de Jonge 1984). The added tracer mixes and equilibrates with the natural DIC-pool of the overlying water and gradually diffuses into the benthic community. In permeable sediments, percolation approaches that facilitate efficient tracer distribution within the photic zone have been adopted (Jönsson 1991). After a given incubation period, the surface sediment is collected and the concentration of radioactively-labeled organic carbon is determined (Matheke and Horner 1974). The technique is very sensitive, but requires the determination of the specific DIC 


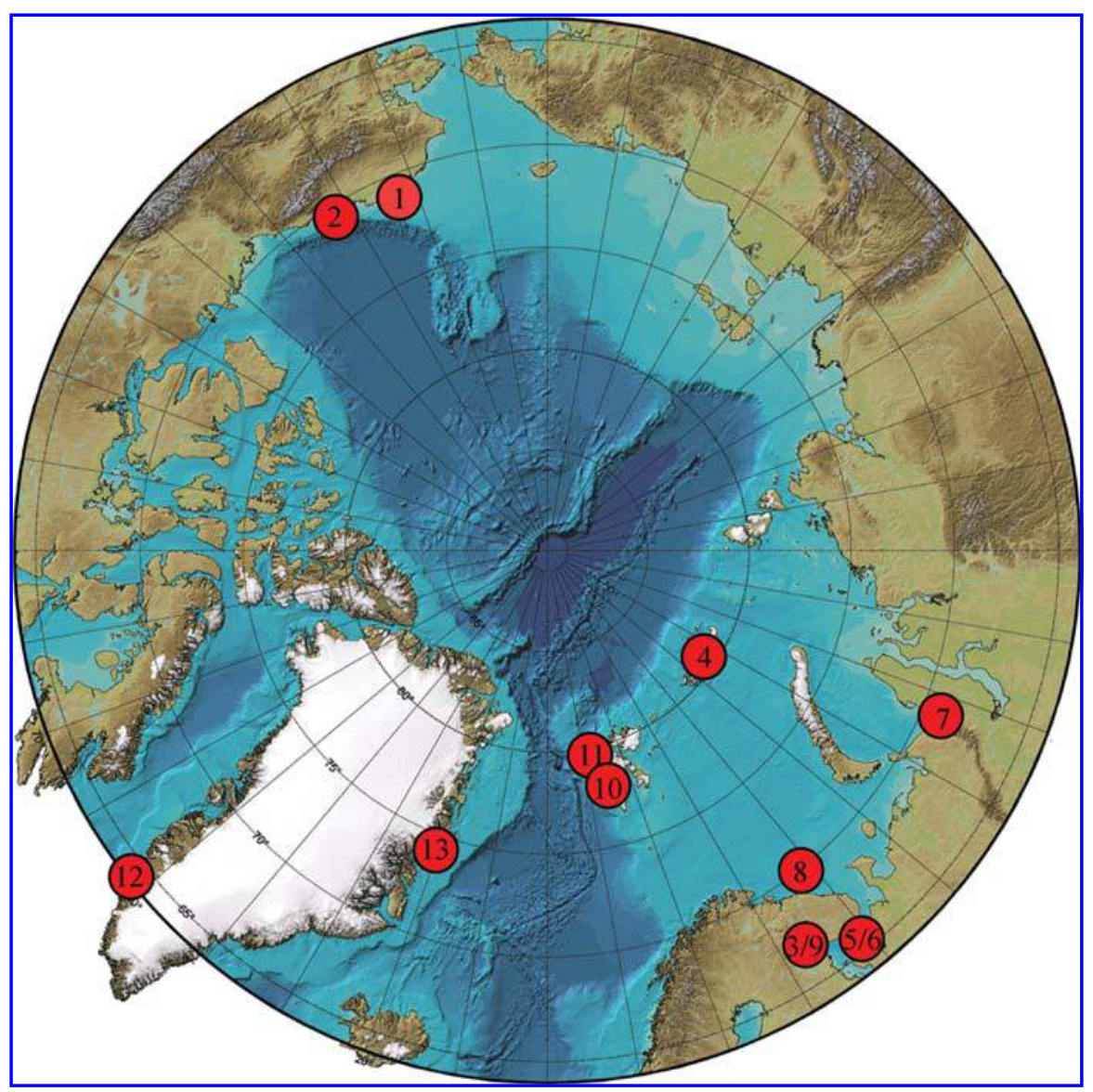

Figure 2 Map of the Arctic region indicating positions where benthic microalgal studies have been performed (red dots).

In some instances, the Russian studies did not indicate the exact positions, but the positions are estimated from the context described in the papers. The individual studies are: 1. Matheke and Horner (1974); 2. Horner and Schrader (1982); 3. Kuznetsov (1991); 4. Kuznetsov (2002); 5. Bondarchuk (1974); 6. Bondarchuk 1980; 7. Kuznetsov et al. (1998); 8. Kuznetsov (2005); 9. Kuznetsov and Strogaya (1989); 10. J. Woelfel (unpublished data) 11. K. Hancke (unpublished data); 12. B. Eyre (unpublished data); 13. Glud et al. (2002).

The Figure is modified from Jakobsson et al. (2008) and published with kind permission from the authors of the quoted article.

labeling in the microenvironment of the active microalgae. Intact microphytobenthic communities are characterized by extensive temporal and spatial variability and by steep concentration gradients of solutes and light. This makes it very difficult to determine the specific DIC labeling experienced by the active microalgae, which is most certainly not constant during a given incubation (Revsbech et al. 1981, de Beer et al. 1997). There is currently no direct way to determine the specific labeling of inorganic carbon pool at the relevant scale, and estimating an average value of this crucial parameter essentially relies on qualified guessing. Due to this problem, the ${ }^{14} \mathrm{C}$ approach is nowadays rarely used to assess benthic productivity.

In principle, the ${ }^{14} \mathrm{C}$ approach quantifies the gross primary production, but depending on the incubation time, some of the fixed ${ }^{14} \mathrm{C}$ can be respired by the microalgae themselves or by heterotrophic bacteria taking advantage of leaking photosynthetic products and exudates. It is very difficult to assess the extent to which this takes place during a given incubation, but it is well-established that heterotrophic activity in natural benthic communities is markedly stimulated by light due to a rapid turnover of freshly produced organic material (Epping and Jørgensen
1996, Kühl et al. 1996, Fenchel and Glud 2000). Therefore, although dependent on the incubation time, the ${ }^{14} \mathrm{C}$ approach generally underestimates true gross photosynthetic activity. By extending the incubation to $24 \mathrm{~h}$ during a natural light/dark cycle it could be argued that the approach expresses the daily net primary production. However, most (and all Arctic) incubations apply an incubation of $\sim 3-5 \mathrm{~h}$ and the gross primary production is calculated after subtracting any ${ }^{14} \mathrm{C}$ fixation rate of parallel dark incubations (Matheke and Horner 1974). In the following, we abbreviate gross primary production as determined by this approach as GPPt ("t" for tracer).

While the benthic ${ }^{14} \mathrm{C}$ incubation technique is rarely used anymore, many studies in Arctic waters are based on this approach and represent a significant contribution to the available database. We have identified seven Arctic studies that have applied the ${ }^{14} \mathrm{C}$ approach to in situ benthic chambers deployed over a depth range of 3-25 m (Table 1). Despite the very limited database and the inherent scatter, maximal rates occurred at very shallow water depths $(<6 \mathrm{~m})$, with little activity at the deepest measuring sites $(20-25 \mathrm{~m})$, presumably as light availability approached the limit of microalgal photosynthetic activity. 
Table 1 Benthic microalgal gross primary production in Arctic ecosystems estimated from in situ chamber incubations enriched by ${ }^{14} \mathrm{C}$-labeled DIC (GPPt).

\begin{tabular}{|c|c|c|c|c|}
\hline 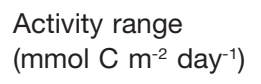 & $\begin{array}{l}\text { Mean } \\
\left(\mathrm{mmol} C \mathrm{~m}^{-2} \text { day }^{-1}\right)\end{array}$ & $\begin{array}{l}\mathrm{Chl} \mathrm{a} \\
\left(\mathrm{mg} \mathrm{m}^{-2}\right)\end{array}$ & $\begin{array}{l}\text { Depth } \\
\text { (m) }\end{array}$ & References \\
\hline $37.6-114.0$ & 75.6 & $\sim 130-380$ & $\sim 5$ & Matheke and Horner (1974) \\
\hline $11.2-65.6$ & 39.8 & $\sim 130-380$ & $\sim 5$ & Matheke and Horner (1974) \\
\hline $0.0-0.2$ & 0.1 & $1-28$ & 7 & Horner and Schrader (1982) \\
\hline $2.0-101.2$ & 32.8 & $\mathrm{NI}$ & 3 & Kuznetsov (1991) \\
\hline $0.2-100$ & 30.0 & $\mathrm{NI}$ & 10 & Kuznetsov (1991) \\
\hline $0.0-95.2$ & 19.8 & $\mathrm{NI}$ & 15 & Kuznetsov (1991) \\
\hline $3.6-19.6$ & 12.0 & $18-72$ & 20 & Kuznetsov (2002) \\
\hline $0.6-4.1$ & $\mathrm{NI}$ & $40-940$ & $1-25$ & Bondarchuk $(1974,1980)$ \\
\hline $\mathrm{NI}$ & 4.6 & $2-640$ & $5-25$ & Kuznetsov et al. 1998 \\
\hline
\end{tabular}

The studies are all seasonal, but the table includes data only from the sea ice-free period.

The Chl a data represent measurements for the uppermost centimeter, but in some instances, only mean values were assessable. $\mathrm{NI}$, no information is available.

\section{Total exchange rates of $\mathrm{O}_{2}$ and DIC}

Generally speaking, the most widely applied procedure to assess the benthic production (or degradation) of organic material is the "whole core incubation" approach, wherein chambers or core liners holding an intact sediment core are either incubated in the laboratory under controlled light conditions or in situ taking advantage of natural irradiance (Cahoon and Cooke 1992, Jahnke et al. 2000, Glud et al. 2008). The net primary production during illumination can then be inferred from the gradual $\mathrm{O}_{2}$ accumulation in the overlying water and/or the concurrent decline in the DIC concentration. The approach is relatively simple, and when larger sediment areas are enclosed, the inherent small-scale patchiness in microalgal biomass can, at least to some extent, be accounted for. One concern is, however, that chambers or cores change the local hydrodynamics. Efficient stirring or mixing of the enclosed water volume during incubations is thus essential and has, in various studies, been accommodated by pumps, impellers, discs or stirrers (Pamatmat and Fenton 1968, Cahoon 1988, Huettel and Gust 1992). It is beyond the scope of this review to discuss pros and cons of various chamber and stirring designs or in situ vs. laboratory-based measurements (for recent reviews, see Tengberg et al. 2005, Glud 2008), but the effect of any imposed stirring on the measured solute exchange rate must be acknowledged.

In benthic communities with a high $\mathrm{O}_{2}$ production (or consumption) rate, the thickness of the diffusive boundary layer $(\mathrm{DBL})$ can significantly affect the net exchange of $\mathrm{O}_{2}$ (Jørgensen and des Marais 1990, Larkum et al. 2003, Glud et al. 2007) and, therefore, affect the derived net photosynthesis. For example, in a benthic microalgal mat, the $\mathrm{O}_{2}$ exchange increased 5-6-fold as the measured DBL thickness was decreased by a factor of $\sim 4$ (Figure 3).

Total $\mathrm{O}_{2}$ or DIC exchange rates measured during illumination quantify the net-photosynthesis (NPPc, c for chambers) of the benthic community, including oxygen consumption related to fauna and microbial respiration. The concurrent gross photosynthetic activity can thus be substantially higher. A common procedure for estimating the gross photosynthesis is to add the exchange rates measured in darkness (or in parallel incubations with opaque chambers) to that of the light incubations (e.g., Eyre and Ferguson 2002). This is a pragmatic approach, but the values should be interpreted with caution for at least two reasons: 1) the infauna of shallow water sediments frequently exhibit a daily variation in their activity level and feeding mode that affects the benthic $\mathrm{O}_{2}$ consumption rate (Rosenberg and Lundberg 2004, Wenzhöfer and Glud 2004), and 2) microbial respiration is typically enhanced in light (Epping and Jørgensen 1996; see also below). Therefore, this approach generally underestimates the true gross photosynthetic activity.

Most studies based on chamber or core incubations infer benthic primary production from change in the $\mathrm{O}_{2}$ concentration. However, electrons released from the light-induced splitting of water (i.e., the $\mathrm{O}_{2}$ formation) can be channeled to a range of other processes in cellhousekeeping, rather than $\mathrm{CO}_{2}$ fixation (Raven and Beardall 1981, Badger et al. 2000, Wagner et al. 2006). Provided any precipitation or dissolution of carbonate can be accounted for, a more direct procedure to quantify primary production could be to measure the daily (24 h) DIC consumption rate. But as $\mathrm{O}_{2}$ is far easier to measure than DIC, the $\mathrm{O}_{2}$ exchange measurements

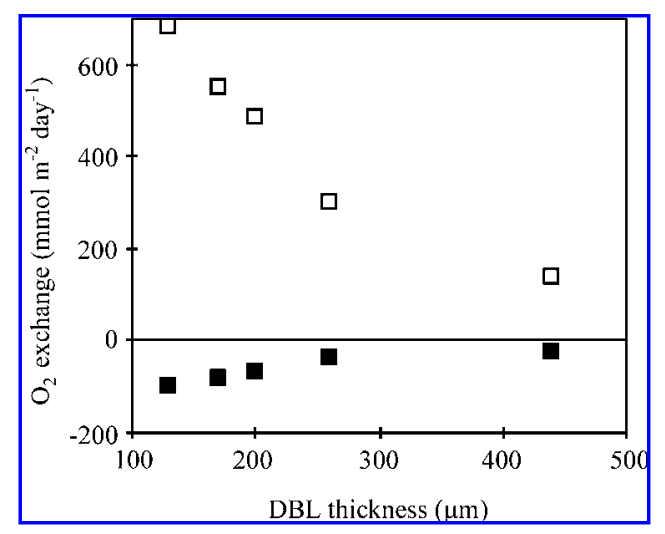

Figure 3 The release and uptake of $\mathrm{O}_{2}$ in a benthic microalgal mat as measured in small benthic chambers (inner diameter $6 \mathrm{~cm}$ ) kept in light (open symbols) and darkness (closed symbols) with different stirring rates.

Parallel $\mathrm{O}_{2}$ microelectrode measurements allowed quantification of the actual diffuse boundary layer (DBL) thickness in the periphery of the chambers at the different stirring speeds of a rotating magnet fixed to the chamber wall in the overlying water. 
Table 2 Benthic microalgal gross primary production in Arctic ecosystems estimated from total $\mathrm{O}_{2}$ exchange measurements (GPPc) by benthic in situ chambers during sea ice-free periods.

\begin{tabular}{lcccl}
\hline $\begin{array}{l}\text { Activity range } \\
\left(\mathrm{mmol} \mathrm{C} \mathrm{m}^{-2} \text { day }^{-1}\right)\end{array}$ & $\begin{array}{l}\text { Mean } \\
\left(\mathrm{mmol} \mathrm{C} \mathrm{m} \mathrm{C}^{-2} \text { day }^{-1}\right)\end{array}$ & $\begin{array}{l}\mathrm{Chl} \mathrm{a} \\
\left(\mathrm{mg} \mathrm{m}^{-2}\right)\end{array}$ & $\begin{array}{l}\text { Depth } \\
(\mathrm{m})\end{array}$ & References \\
\hline $\mathrm{NI}$ & 5.9 & 30 & 5 & Kuznetsov (2005) \\
$\mathrm{NI}$ & 10.1 & 140 & 10 & Kuznetsov (2005) \\
$\mathrm{NI}$ & 16.9 & 122 & 15 & Kuznetsov (2005) \\
$\mathrm{NI}$ & 12.7 & 126 & 20 & Kuznetsov (2005) \\
$\mathrm{NI}$ & 0.8 & 111 & 25 & Kuznetsov (2005) \\
$8.1-21.6$ & 14.8 & $42-347$ & 3 & Kuznetsov and Strogaya (1989) \\
\hline
\end{tabular}

The $\mathrm{Chl} \mathrm{a} \mathrm{data} \mathrm{represent} \mathrm{measurements} \mathrm{for} \mathrm{the} \mathrm{uppermost} \mathrm{centimeter:} \mathrm{in} \mathrm{some} \mathrm{instances} \mathrm{only} \mathrm{mean} \mathrm{values} \mathrm{were} \mathrm{available} \mathrm{for}$ assessment. NI: no information is available.

remain the preferred procedure and $\mathrm{O}_{2}$ exchange is subsequently transformed into a $\mathrm{CO}_{2}$ fixation rate assuming a photosynthetic quotient (PQ). Most measurements of $P Q$ for integrated benthic communities, quantified as the ratio between the exchange of $\mathrm{O}_{2}$ vs. DIC, range between 0.9 and 1.3, largely depending on the light and nutrient availability (Cammen 1991, Cahoon and Cooke 1992, Longphuirt et al. 2007, Taddei et al. 2008). Generally a value of 1.2 is applied to benthic communities, i.e., 1.0 carbon atom is fixed per $1.2 \mathrm{O}_{2}$ molecule produced. Based on 50 incubations of sediment cores collected over a water depth range of 5-30 m and exposed to light levels between 6 and $100 \mu \mathrm{mol}$ photons $\mathrm{m}^{-2} \mathrm{~s}^{-1}$, the community $P Q$ of a high Arctic sediment averaged 1.19 \pm 0.48 (Glud et al. 2002). Based on these measurements, and in order to be consistent with most studies conducted at lower latitudes, we have chosen to apply a conversion factor of 1.2 to derive the benthic gross primary production (GPPc) from the sum of $\mathrm{O}_{2}$ exchange measured in darkness and light with benthic incubation chambers [the respiratory quotient $(R Q)$ is thereby assumed to be the reciprocal of $P Q]$.

We have identified two in situ studies (Kuznetsov and Strogaya 1989, Kuznetsov 2005) from the Arctic that used chambers for quantifying benthic microphytic production (Table 2). The values align with the GPPt data of Table 1, but rather than a straightforward depth relationship, maximal phototrophic activity occurred at intermediary water depths.

One published High Arctic study used laboratory core incubations under well-defined irradiance to quantify the productivity of benthic microalgae (Glud et al. 2002). These data are plotted against irradiance along with those from three unpublished studies in Figure 4. As expected, the relationship between GPPc and light exposure exhibits significant scatter, mainly reflecting the small- and large-scale variation in microalgal biomass. The cores were sampled at water depths from 2 to $30 \mathrm{~m}$, but there is no significant depth trend in the data. This is in accord with the observation that benthic diatoms quickly optimize their photosynthetic apparatus to the available irradiance and that any depth-specific light acclimatization coheres when collected cores are exposed to similar light conditions (Kühl et al. 2001, Glud et al. 2002). Fitting a Platt function to the data (Platt et al. 1980) improved a simple linear fit to the compiled dataset and suggested a photosynthetic capacity $\left(P_{m}\right)$ of $39 \mathrm{mmol} \mathrm{m}^{-2}$ day-1 $^{-1}$ and an "index of light adaptation" $\left(E_{k}\right)$ of $86 \mu \mathrm{mol}$ photons $\mathrm{m}^{-2} \mathrm{~s}^{-1}$ (Figure 4). The derived Platt equation is by no means universal for Arctic sediments and will, presumably, change as the data base hopefully increases with future studies. It does, however, provide a proxy for extrapolating local production rates to larger regional scales using information on the available irradiance. To extrapolate the studies in Figure 4 to in situ activity during summer, we assessed the average in situ light availability from information on light extinction coefficients of the water column, direct measurements of the down-welling irradiance and day length in the respective studies (Table 3).

The recent introduction of the eddy correlation to aquatic biology offers a strong and complementary tool to chamber incubations (Berg et al. 2003, 2007). The technique can be used for in situ, non-invasive quantification of the benthic $\mathrm{O}_{2}$ exchange, integrating the activity of $50-100 \mathrm{~m}^{2}$ of the sea bed. At present, there are very few studies applying the technique to aquatic sediments (Berg et al. 2003, 2009, Kuwae et al. 2006, Brand et al. 2008) but as yet, no investigations have used eddy correlation to study benthic primary production.

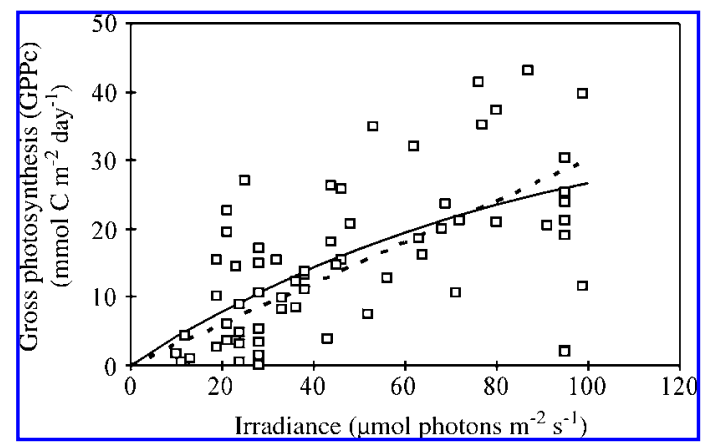

Figure 4 Gross primary production calculated from $\mathrm{O}_{2}$ exchange rates measured in sediment cores exposed to welldefined irradiance levels in the laboratory (GPPc).

The data are extracted from Glud et al. (2002) and three unpublished studies by J. Woelfel, K. Hancke and B. Eyre, respectively (see also Figure 1). The compiled data were fitted by a simple linear equation $\left(\mathrm{GPP}_{\mathrm{c}}=0.3 \mathrm{E}\right.$; dotted line), where " $\mathrm{E}$ " is the irradiance $\left(R^{2}=0.29\right)$ and a Platt function $\left[G P P c=P_{m}\left(1-E X P\left(\alpha E_{z} /\right.\right.\right.$ $\left.\left.\left.P_{m}\right)\right)\right]$, where " $P_{m}$ " - the photosynthetic capacity - equaled $39 \mathrm{mmol} \mathrm{m}^{-2}$ day $^{-1} ; \alpha$ - the initial slope of GPPc - equaled 0.45 , and " $E_{\mathrm{z}}$ " is the irradiance $\left(R^{2}=0.34\right)$. Both fits were forced through $(0,0)$. The index of light adaptation $E_{k}=P_{m} / \alpha$ amounted to $86 \mathrm{mmol}$ photons $\mathrm{m}^{-2}$ day $^{-1}$. Two points included in the fit lie outside the boundaries of the axes. 
Table 3 Benthic microalgal gross primary production in open-water Arctic ecosystems as estimated from total $\mathrm{O}_{2}$ exchange measurements (GPPc) of laboratory-based core incubations.

\begin{tabular}{|c|c|c|c|c|c|}
\hline $\begin{array}{l}\text { Activity range } \\
\left(\mathrm{mmol} \mathrm{C} \mathrm{m}^{-2} \text { day }^{-1}\right)\end{array}$ & $\begin{array}{l}\text { Irradiance } \\
\left(\mu \mathrm{mol} \text { photons } \mathrm{m}^{-2} \mathrm{~s}^{-1}\right)\end{array}$ & 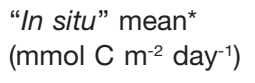 & $\begin{array}{l}\text { Chl a } \\
\left(\mathrm{mg} \mathrm{m}^{-2}\right)\end{array}$ & $\begin{array}{l}\text { Depth } \\
\text { (m) }\end{array}$ & References \\
\hline $36-90$ & 95 & 112 & 136 & 5 & J. Woelfel (unpublished data) \\
\hline $16-46$ & 95 & 25 & 30 & 10 & J. Woelfel (unpublished data) \\
\hline $10-36$ & 95 & 10 & 11 & 15 & J. Woelfel (unpublished data) \\
\hline $10-46$ & 95 & 6 & 8 & 20 & J. Woelfel (unpublished data) \\
\hline $19-26$ & 95 & 2 & 2 & 30 & J. Woelfel (unpublished data) \\
\hline $15-21$ & 95 & 29 & 34 & 5 & J. Woelfel (unpublished data) \\
\hline $19-25$ & 95 & 16 & 19 & 10 & J. Woelfel (unpublished data) \\
\hline $1-3$ & 95 & 1 & 1 & 15 & J. Woelfel (unpublished data) \\
\hline $1-3$ & 95 & 1 & 1 & 20 & J. Woelfel (unpublished data) \\
\hline $0-5$ & 95 & $<1$ & $<1$ & 30 & J. Woelfel (unpublished data) \\
\hline $18-34$ & 140 & 36 & 3 & 1 & K. Hancke (unpublished data) \\
\hline $40-54$ & 200 & 42 & $\mathrm{NI}$ & 2 & B. Eyre (unpublished data) \\
\hline $1-21$ & $21-91$ & 34 & 75 & 5 & Glud et al. (2002) \\
\hline $1-24$ & $6-69$ & 24 & 66 & 10 & Glud et al. (2002) \\
\hline $1-43$ & $12-87$ & 12 & 186 & 20 & Glud et al. (2002) \\
\hline $1-27$ & $11-53$ & 5 & 92 & 30 & Glud et al. (2002) \\
\hline
\end{tabular}

The $\mathrm{Chl}$ a data represent measurements for the uppermost centimeter; in some instances only mean values were available for assessment. NI: no information is available.

* The actual laboratory-based measurements were extrapolated to estimate average in situ irradiance at the sampling sites using recorded light levels and light extinction coefficients of the water column during the open-water period.

\section{Oxygen microsensor measurements}

The prime advantage of using chambers or cores (and eddy correlation) for quantifying benthic exchange rates is that their application is relatively simple and averages out small scale variations. However, such methods represent a "black-box" approach and only provide limited insight into the vertical and horizontal activity distribution or into the microenvironment in which the microbenthic phototrophic activity takes place. Oxygen microelectrode measurements allow a very detailed characterization of the distribution, production and consumption of $\mathrm{O}_{2}$ at a given point in time (Revsbech et al. 1981, Epping et al. 1999) and multiple measurements thereby complement chamber incubations well. From measured microprofiles, the diffusive export of $\mathrm{O}_{2}$ from the photic zone can be quantified as the sum of the upward and downward flux, and when converted into carbon equivalents, this represents the net primary production of the community (NPPm) (Figure 5). The upward flux is essentially what is quantified in the NPPc measured by chamber or core incubations and generally accounts for $70-90 \%$ of the NPPm (Epping and Jørgensen 1996, Kühl et al. 1996, Wenzhöfer et al. 2000, Christensen et al. 2003).

Oxygen microsensors also allow quantification of gross primary production (GPPm) by the light-dark-shift technique (Revsbech and Jørgensen 1983). Basically, this method calculates gross photosynthesis from the rate at which the $\mathrm{O}_{2}$ concentration at a given point declines immediately after onset of darkness. The approach assumes that the $\mathrm{O}_{2}$ gradients and respiration remain unaffected during the light/dark shift, and detailed investigations have proven that this is essentially correct, as long as the $\mathrm{O}_{2}$ decline is determined within the first second of darkness (Glud et al. 1992, Lassen et al. 1998). This approach actually resolves the true gross primary production of the community, provided the applied $P Q$ reflects the relationship between $\mathrm{O}_{2}$ production and DIC fixation under the given conditions.

Figure 5 shows an example of the level of detail that can be obtained by microsensor measurements and degree of complexity in deriving an estimate of benthic productivity from $\mathrm{O}_{2}$ exchange measurements with ben-

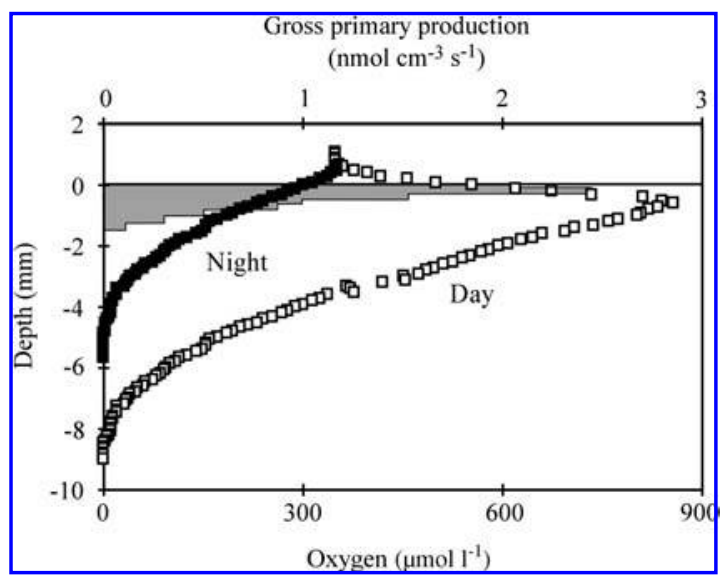

Figure 5 Oxygen microprofiles measured in a diatom-dominated community of benthic microalgae.

Black symbols represent measurements in darkness, while open symbols are measurements at a down-welling irradiance of $450 \mu \mathrm{mol}$ photons $\mathrm{m}^{-2} \mathrm{~s}^{-1}$. Gray bars represent the gross photosynthesis as measured by the "light-dark-shift" technique. Jup represents the upward-directed $\mathrm{O}_{2}$ flux as calculated from $\left(\mathrm{J}_{\text {up }}=\mathrm{Do} \mathrm{dC} / \mathrm{dz}\right)$, where Do is the molecular diffusion coefficient for $\mathrm{O}_{2}$ under the experimental conditions, and $\mathrm{C}$ is the $\mathrm{O}_{2}$ concentration at depth $Z$ within the diffuse boundary layer (DBL; the same approach is applied to estimate $\mathrm{O}_{2}$ consumption from the microprofile measured in darkness). The downward $\mathrm{O}_{2}$ flux is quantified by the same relation, but this time applying the tortuosity-corrected diffusion coefficient of the sediment matrix. The sum of $J_{\text {up }}$ and $J_{\text {down }}$ provides the net photosynthetic activity of the photic zone. 
thic chambers or whole cores. The benthic $\mathrm{O}_{2}$ consumption in darkness amounted to $13.0 \mathrm{mmol} \mathrm{m}^{-2}$ day $^{-1}$, while the $\mathrm{O}_{2}$ efflux from the photic zone (the upper $1.6 \mathrm{~mm}$ ) during light equaled $81.7 \mathrm{mmol} \mathrm{m}^{-2}$ day $^{-1}$, of which $74 \%$ (60.1 $\mathrm{mmol} \mathrm{m}^{-2}$ day $^{-1}$ ) diffused upwards into the overlying water and the residual $21.6 \mathrm{mmol} \mathrm{m}^{-2}$ day $^{-1}$ sustained $\mathrm{O}_{2}$ consumption in the deeper sediment layers (Figure 5). The concurrent depth-integrated gross production of $\mathrm{O}_{2}$, measured by the light-dark shift technique, was $117.7 \mathrm{mmol} \mathrm{m}^{-2}$ day $^{-1}$, meaning that the respiration within the illuminated photic zone (the upper $1.6 \mathrm{~mm}$ ) was $36.0 \mathrm{mmol} \mathrm{m}^{-2}$ day $^{-1}$ (117.7-81.7). The benthic $\mathrm{O}_{2}$ consumption during light thus amounted to $57.6 \mathrm{mmol} \mathrm{m}^{-2}$ day $^{-1}(36.0+21.6)$, which is $>4$ times higher than $\mathrm{O}_{2}$ consumption in darkness. The stimulated activity during light was caused by two factors i) an increased $\mathrm{O}_{2}$ consumption within the photic zone and ii) a deeper oxic penetration zone within which $\mathrm{O}_{2}$ was consumed. If we apply the calculation procedure that is generally applied to chamber incubation, the "GPPc" is the sum of the $\mathrm{O}_{2}$ consumption in darkness and the upward $\mathrm{O}_{2}$ release in light (converted into $C$ equivalents), which sums to $60.9 \mathrm{mmol}$ C $\mathrm{m}^{-2}$ day $^{-1}[(13+60.1) / 1.2]$. In reality, the NPPm is $68.0 \mathrm{mmol} \mathrm{C} \mathrm{m}^{-2}$ day $^{-1}(81.7 / 1.2)$ and the GPPm is $98.0 \mathrm{mmol} \mathrm{C} \mathrm{m}^{-2}$ day $^{-1}$ (117.7/1.2). This example illustrates how the widely-applied chamber approach underestimates actual benthic productivity and how confusing use of the terms net and gross primary production is in the existing literature. The example also illustrates the detailed insights that can be provided into $\mathrm{O}_{2}$ turnover at a given spot using microsensor measurement. The approach is, however, very time consuming - a set of microprofiles resolving the $\mathrm{O}_{2}$ distribution and the GPPm at a given spot for a single level of irradiance typically takes about 40-50 min, and given the natural variability of the sea-bed it is a non-trivial task to extrapolate the findings from one or a few measurements to a larger area. This remains the prime limitation of the microsensor measuring approach.

To the best of our knowledge, there are only two microsensor studies on benthic microalgal activity in the Arctic (Glud et al. 2002, Hancke and Glud 2004). In the first, sediment cores were recovered from 10 to $30 \mathrm{~m}$ water depth and were then incubated under similar light, temperature and salinity conditions in the laboratory for two days. Subsequently, $\mathrm{O}_{2}$ microprofiles were measured in the diatom cover, and the compiled data exhibited a good PE-relationship, without any light-inhibition at the irradiances applied (Figure 6). Benthic microalgal communities rarely exhibit light inhibition because i) a downward migration of motile cells counteracts inhibiting light levels at the surface due to the extremely steep light gradients in such communities (Kühl et al. 1997), and ii) a gradual expansion of the photic zone with increasing irradiance compensates for any potential activity decline at the surface (Epping and Jørgensen 1996, Kühl et al. 1996, Christensen et al. 2003).

The fitted Platt equation of Figure 6 shows a photosynthetic capacity $\left(P_{m}\right)$ of $67 \mathrm{mmol} \mathrm{m}^{-2}$ day $^{-1}$ and an "index of light adaptation" $\left(E_{k}\right)$ of $27 \mu \mathrm{mol}$ photons $\mathrm{m}^{-2}$ $\mathrm{s}^{-1}$ for net photosynthesis (NPPc). When comparing with the GPPc-Platt relation (Figure 4), it is important to realize

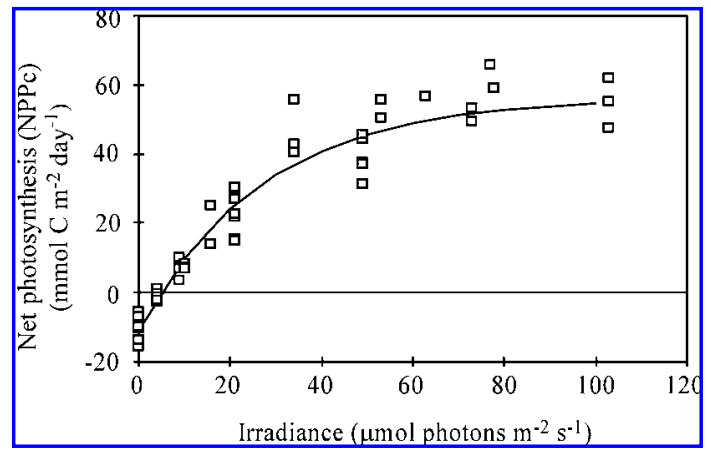

Figure 6 Net primary production calculated from $\mathrm{O}_{2}$ microprofiles measured in sediment cores exposed to well-defined irradiance levels in the laboratory (NPPC).

The data are extracted from Glud et al. 2002 (see also Figure 1). The compiled data were fitted by a Platt function including a "respiration" term (R) $\left[N P P c=P_{m}\left(1-E X P\left(-\alpha E / P_{m}\right)\right)\right]-R$, where " $P_{m}$ " - the photosynthetic capacity - was $67 \mathrm{mmol} \mathrm{m}^{-2}$ day-1; $\alpha$ - the initial slope of GPPc - was 2.5, and R was $10.7 \mathrm{mmol}$ $\mathrm{m}^{-2}$ day ${ }^{-1}$; " $\mathrm{E}$ " is the irradiance $\left(\mathrm{R}^{2}=0.70\right)$.

that the two relationships are based on different techniques and, as explained above, this causes the otherwise inconsistent observation that $P_{m}$ for gross primary production (GPPc as derived from core incubations) is lower than the $\mathrm{P}_{\mathrm{m}}$ for the net primary production (NPPm as derived from microprofile measurements). The light compensation point, where the benthic $\mathrm{O}_{2}$ consumption balances the $\mathrm{O}_{2}$ production (i.e., the light level at which the net $\mathrm{O}_{2}$ exchange is zero $\mathrm{mmol} \mathrm{m}^{-2}$ day $^{-1}$ ) amounted to $4.7 \mu \mathrm{mol}$ photons $\mathrm{m}^{-2} \mathrm{~s}^{-1}$. This value essentially defines the threshold irradiance required to sustain net primary production of the communities investigated at the given experimental conditions. The data in Figure 6 were measured in patches of benthic microphytes and ignored patches of bare sediment. Accounting for in situ coverage of benthic microalgae and mean daily light availability at the respective water depths, NPPm for the study was calculated and is presented in Table 4.

The only other Arctic microsensor study on benthic microalgae was performed on sediment cores recovered below snow covered sea-ice with very low phototrophic biomass (the sediment surface Chl a level was $2.7 \mathrm{mg} \mathrm{m}^{-2}$; Hancke and Glud 2004). This study focused on shortterm temperature effects on respiration and photosynthesis of benthic communities dominated by diatoms rather than on quantifying benthic productivity. It was shown that both respiration and photosynthesis

Table 4 Benthic microalgal net primary production in an openwater Arctic ecosystem as estimated from microsensor measurements (NPPm) in the laboratory and extrapolated to in situ activity using information on light availability and benthic microalgal cover (BMC).

\begin{tabular}{lcl}
\hline $\begin{array}{l}\text { Mean } \\
\left(\mathrm{mmol} \mathrm{C} \mathrm{m} \text { day }^{-1}\right)\end{array}$ & $\begin{array}{l}\text { Depth } \\
(\mathrm{m})\end{array}$ & $\begin{array}{l}\text { In situ BMC } \\
(\%)\end{array}$ \\
\hline 32.0 & 5 & 23 \\
31.3 & 10 & 26 \\
14.8 & 20 & 73 \\
9.3 & 30 & 36 \\
\hline
\end{tabular}

Glud et al. (2002). 
increased with temperature, but that a stronger $Q_{10}$ response of heterotrophic activity gradually lead to reduced net benthic productivity as the temperature increased (Hancke and Glud 2004). The extent to which this observation is the result of the short-term nature of the experiment (days to weeks), and whether seasonal increases in temperature can shift shallow-water Arctic sediments into a more heterotroph-dominated status in late summer remain to be investigated.

\section{Discussion}

\section{Relative importance of benthic vs. pelagic microalgal productivity}

Growing directly at the sediment surface, benthic microalgae can exploit nutrients released by the underlying biogeochemical mineralization processes and can thus deprive the pelagic community of nutrients. In contrast, pelagic phototrophs can better exploit the down-welling irradiance as compared to communities constrained to a narrow zone on the sediment surface. Thus, nutrient availability often regulates the relative importance of pelagic vs. benthic microalgal productivity. Eutrophic settings favor pelagic productivity, while oligotrophic settings favor benthic productivity (CharpyRoubaud and Sournia 1990, Maclntyre et al. 1996). Even though rivers can carry nutrient-enriched water and induce plumes of stimulated pelagic production that reduce the benthic light availability locally (Parsons et al. 1988, Springer and McRoy 1993), Arctic coastal waters are pristine with low nutrient levels. Consequently, they can be expected to host a relatively large benthic productivity.

Several of the original benthic studies in Tables 1-4 performed parallel measurements of the pelagic productivity and have provided estimates on the relative importance of pelagic vs. benthic microalgae (Table 5). Except for one study, these estimates show a complete dominance of benthic productivity at shallow depths, which tails off towards deeper waters. But even at the deepest investigated site $(30 \mathrm{~m})$, pelagic and benthic microalgal productivity were of similar magnitude, suggesting that benthic microalgal activity dominated in systems shallower than $30 \mathrm{~m}$. Note, however, that Table 5 excludes

Table 5 Relative proportion of benthic microalgal primary production vs. pelagic primary production in Arctic coastal environments.

\begin{tabular}{lll}
\hline $\begin{array}{l}\text { Benthic } \\
\text { contribution }(\%)\end{array}$ & $\begin{array}{l}\text { Water depth } \\
(\mathrm{m})\end{array}$ & Study \\
\hline 76 & 5 & Matheke and Horner (1974) \\
3 & 3 & Horner and Schrader (1982) \\
75 & 3 & Kuznetsov (1991) \\
45 & 10 & Kuznetsov (1991) \\
40 & 15 & Kuznetsov (1991) \\
8 & $0-20$ & Kuznetsov (2002) \\
66 & $0-20$ & Kuznetsov et al. (1998) \\
96 & 5 & Glud et al. (2002) \\
92 & 10 & Glud et al. (2002) \\
72 & 20 & Glud et al. (2002) \\
51 & 30 & Glud et al. (2002) \\
\hline
\end{tabular}

any potential contribution from macrophytes, which may dominate ecosystem production in some Arctic settings (Krause-Jensen et al. 2007).

The relative importance of various photosynthetic communities has also been assessed using diver-operated pulse amplitude modulation (PAM) fluorometry (Schreiber 2005, Diving-PAM, www.walz.com). Measurements in an ice-covered coastal ecosystem off Hokkaido, Japan concluded that benthic microalgae were responsible for $13-66 \%$ of the ecosystem production at water depths ranging from 3-9 m (McMinn et al. 2005). However, such indirect approaches involving interpretation of variable chlorophyll fluorescence measurements are based on many assumptions about the photosynthetic apparatus and the coupling between electron transport and carbon fixation of the different organisms - assumptions that are difficult to test or justify with natural samples (Kühl et al. 2001), and, therefore, such studies can often at best be regarded as indicative.

The observations in Table 5 are in contrast to findings of Kuznetsov (2005), who estimated that the annual pelagic productivity exceeded the benthic microalgal productivity by factors of 1.3-2.8 (average 1.7) when integrated for sediments residing at $0-20 \mathrm{~m}$ depth in areas off the Kola Peninsular, Franz Josef Land, eastern Svalbard, West Novaya Zemlya and in the Pechora Sea. These values were, however, presented in abstract format without any explanation on how measurements and extrapolations were performed.

\section{Extrapolating benthic microalgal productivity in time and space}

Extrapolations of the limited database on productivity of Arctic benthic microalgae to regional scales requires establishment of a relation to simple parameters that are measured more frequently than benthic primary production. The number of studies quantifying benthic $\mathrm{Chl}$ a concentration is much larger than the number of studies quantifying microalgal activity, and $\mathrm{Chl}$ a has often been used as an indication of the activity of benthic microalgae (Cahoon 1999, Vetrov and Romankevich 2004). All the original studies of Arctic benthic microalgae (Tables 1-4) provided estimates on biomass expressed as Chl a concentration in the sediment surface layer (mostly $0-1 \mathrm{~cm}$ ). Minimum or maximum values of $\mathrm{Chl} a$ and benthic productivity do correlate (Tables 1-4), but overall there is no clear relationship between these two parameters. A simple linear relationship of the compiled data set expresses an $R^{2}$ value of only 0.23 , and elimination of some obvious outliers does not markedly improve the relationship (data not shown). However, this may not be too surprising as the photic zone typically extends only a few $\mathrm{mm}$ into the sediment, and Chl a concentration averaged over the uppermost $\mathrm{cm}$ therefore only poorly represents the active phototrophic biomass (Kühl et al. 1997, Kühl 2005). Benthic Chl a concentrations may also be confounded by inactive degradation products originating from pelagic microphytes, senescent or saprophytic living microphytes or spores (Sun et al. 1994). Furthermore, it is wellestablished that one light-adaptive strategy of benthic microalgae is to regulate their cell-specific Chl a concentration (Blanchard and Montagna 1992). Clearly extract- 
able Chl a concentration is often a poor proxy for extrapolating benthic productivity to wider areas.

Given the fact that benthic microalgae are generally well supplied with nutrients, it seems reasonable to assume that community productivity is light-limited and that light availability could serve as a good proxy for benthic primary production.

The minimum light requirement for benthic microalgae is not well defined, but communities of obligate benthic diatoms have been encountered down to almost $200 \mathrm{~m}$ water depth where the maximum light availability was $<0.2 \mu \mathrm{mol}$ photons $\mathrm{m}^{-2} \mathrm{~s}^{-1}$ (McGee et al. 2008). However, a visual coverage of benthic microalgae is rarely observed in water depths $>40 \mathrm{~m}$ (Cahoon 1999), and the minimal light intensities at which polar and subpolar microphytobenthic activity have been recorded range between 0.5 and $2.5 \mu \mathrm{mol}$ photons $\mathrm{m}^{-2} \mathrm{~s}^{-1}$ (Palmisano et al. 1985, Grant 1986, Karsten et al. 2006).

Assuming PAR-extinction coefficients of coastal waters ranging between 0.12 and $0.16 \mathrm{~m}^{-1}$ for clear and turbid water, respectively (Jerlov 1970), and assuming an average down-welling irradiance during midsummer in the high Arctic of $414 \mu \mathrm{mol}$ photons $\mathrm{m}^{-2} \mathrm{~s}^{-1}$ (Glud et al. 2002), a diel average of $0.5 \mu \mathrm{mol}$ photons $\mathrm{m}^{-2} \mathrm{~s}^{-1}$ would reach down to 42 and $52 \mathrm{~m}$ in "turbid" and "clear" waters, respectively. The corresponding values for $2.5 \mu \mathrm{mol}$ photons $\mathrm{m}^{-2} \mathrm{~s}^{-1}$ would be 30 and $46 \mathrm{~m}$. This simple calculation does not account for any changes in spectral composition, but demonstrates that benthic microalgae can be photosynthetically active down to significant water depth in the Arctic region - especially in offshore, clear waters.

Based on remote sensing-derived estimates of light extinction coefficients and PAR distribution in surface waters in the Arctic, Gattuso et al. (2006) proposed that the relative proportion $(S)$ of the coastal seabed receiving light above a given threshold $\left(E_{z}\right.$ mol photons $\mathrm{m}^{-2}$ day $\left.^{-1}\right)$ during the open-water period in summer on average could be estimated as:

\section{$S=16.0-13.6 \log \left(E_{z}\right)+1.5 \log \left(E_{z}^{2}\right)+0.7 \log \left(E_{z}^{3}\right)$.}

The relationship accounts for the estimated relative distribution of case 1 water (light attenuation due to presence of phytoplankton), which cover $\sim 66 \%$ of the investigated area, and case 2 water [light attenuation due to phytoplankton, suspended particles and matter; see Morel and Prieur (1977)]. The relationship predicts that, on average, $35 \%\left(\sim 2.1 \times 10^{6} \mathrm{~km}^{2}\right)$ of the coastal Arctic seabed receives a daily average irradiance $>0.5 \mu \mathrm{mol}$ photons $\mathrm{m}^{-2} \mathrm{~s}^{-1}$ during the open-water period. Correspondingly, $25 \%, 17 \%$ and $5 \%$ of the coastal Arctic seabed would receive average irradiances above 2.5, 10 and $100 \mu \mathrm{mol}$ photons $\mathrm{m}^{-2} \mathrm{~s}^{-1}$, respectively, during the open-water period. Deriving benthic light availability on larger scales from remote sensing is an innovative approach, but it is obviously associated with a number of shortcomings. Measurements can only be performed when cloud and ice cover allow, the spatial and temporal resolution is limited and the distribution of case 1 and case 2 waters can be only crudely assessed at present. Furthermore, the importance of nepheloid layers and high turbidity water, which will both increase light extinction, is poorly defined (Gattuso et al. 2006). Nevertheless such approaches are thus far the best tools available for a first estimation of benthic microalgal productivity over larger scales in the Arctic.

Using the PE relation in Figure 4 and the equation for light availability derived by Gattuso et al. (2006), we can extrapolate the estimated gross primary production (GPPc) derived by chamber/core incubations to the entire Arctic region. In essence, the same calculation could be made for the PE relation of $\mathrm{NPP}_{\mathrm{m}}$ derived from microsensor measurements. However, as these data only represent conditions within well developed microalgal patches, the small scale variations in biomass have to be accounted for during extrapolating - and, as seen in Figure 1, this is a non-trivial task. Such an exercise has, however, been carried out and discussed in a confined area of Young Sound, NE Greenland (Glud et al. 2002).

On average, the daily $\mathrm{GPP}_{\mathrm{c}}$ extrapolated to the Arctic coastal region amounts to an average of $1.8 \times 10^{5} \mathrm{t} \mathrm{C}$ day $^{-1}$ during the open-water period. The average openwater period for the coastal Arctic (water depth 0-50 m) can be estimated from remote sensed sea-ice concentrations available at the NSIDC (National Snow and Ice Data Center, USA). The average value amounts to 120 days using a grid size of $12.5 \mathrm{~km}$ and a $25 \%$ threshold of sea-ice concentration (Phil Hwang, unpublished data). However, as grids holding any coastline are masked out by such procedures, areas with land-fast ice are under-represented, and 120 days of open-water period must represent a maximum value. On the basis of selected publications, Cahoon (1999) estimated the average open-water period for the Arctic to be 90 days. Using this value, the annual benthic microalgal primary production amounted to $1.6 \times 10^{7} \mathrm{t} \mathrm{C}_{\text {year }}{ }^{-1}$ in the Arctic. A longer open-water period would increase the estimated primary production proportionally. This estimate does not include potential contributions during sea-ice cover, but even though some reports have documented "shade-adapted" benthic photosynthesis below sea-ice, reflectance and absorbance in snow-covered sea-ice is so high that such contributions must be marginal (Palmisano et al. 1985, Glud et al. 2007b). The integrated benthic primary production may seem marginal as compared to the existing estimates on the pelagic productivity of the Arctic oceans ranging from 21 to $42 \times 10^{7} \mathrm{t} \mathrm{C}$ year-1 (Subba-Rao and Platt 1984, Pabi et al. 2008). However, most of the benthic primary production is confined to regions with water depths shallower than $30-40 \mathrm{~m}$, regions that account for only $\sim 10-14 \%$ of the Arctic oceans, and in those areas, the relative benthic contribution to the total community primary production is correspondingly higher as also reflected in Table 5.

Light availability generally declines exponentially with water depth. Although we used different procedures for quantifying benthic productivity and for extrapolating the data to seasonal time scale, our compiled data (Tables 1-4) show a quasi exponential decline with increasing water depth (Figure 7). The inherent scatter in the data set is partly a result of compiling data obtained with different measuring procedures, but it can also be related to variations in the light extinction coefficients between 


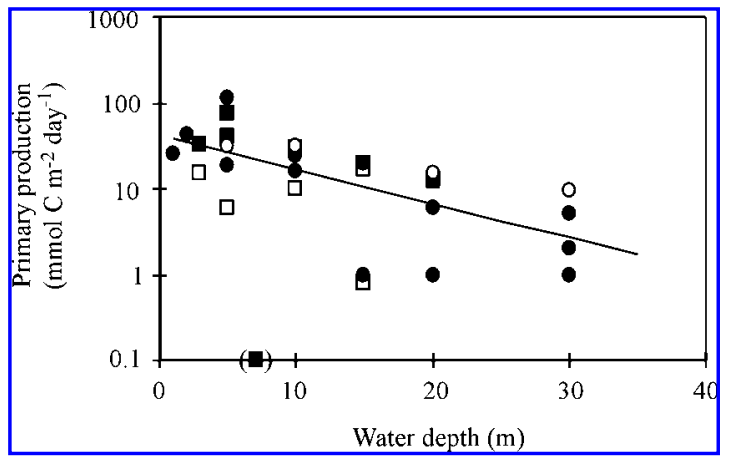

Figure 7 Benthic microalgal primary production (PP) derived from Tables 1-4 plotted against waters depth ( $\mathrm{z}$ ) at the respective study sites (filled squares Table 1, open squares Table 2 , filled circles Table 3, open circles Table 4). The compiled data (except for point in brackets) were fitted with $\mathrm{PP}=41.5 \mathrm{e}^{-0.0911 z}$ $\left(R^{2}=0.41\right)$.

the different study areas. The natural variability between study areas apparently overrides any systematic bias related to the fact that different measuring procedures have been applied and that the dataset consist of a mixture of NPP and GPP estimates. However, our simple relationship offers another way to extrapolate the limited database to a regional scale by simply multiplying the productivity-depth relation (42- $\mathrm{e}^{-0.911 z}$ ) to the bathymetry of the coastal Arctic oceans. Such calculation gives an average benthic microalgal primary production of

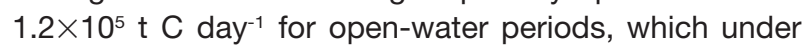
the assumption of an average open-water period of 90 days (Cahoon 1999) translates into an annual benthic microalgal primary production in the Arctic coastal ocean of $1.1 \times 10^{7} \mathrm{t} \mathrm{C}$ year-1. This figure is $\sim 30 \%$ lower than our estimate of $1.6 \times 10^{7} \mathrm{t} \mathrm{C}$ year-1 using the light relationship above (Figure 4), but acknowledging the different procedures and the limited database, the estimates are surprisingly consistent.

\section{Concluding remarks}

The limited database (Tables 1-4) clearly suggests that benthic microalgae contribute significantly to the coastal ecosystem production in Arctic waters. In fact, our compilation indicates that benthic microalgal productivity is of similar magnitude or even exceeds the pelagic productivity in coastal areas with water depths $<30 \mathrm{~m}$. Extrapolation from the current data base using empirical relations between light availability, water depth and benthic microalgal activity estimates a contribution of 1.1$1.6 \times 10^{7}$ t C year-1 $^{-1}$ to the coastal Arctic ecosystem.

The entire Arctic region is, however, grossly undersampled and further studies on benthic primary production should be encouraged. As in temperate regions, certain coastal areas are especially under-explored these include rocky and sandy sediments, and no measurements have been performed in shallow off-shore areas. The introduction of the eddy correlation technique to aquatic biology (Berg et al. 2003) provides an opportunity to improve this situation - especially if linked to benthic observatories - by facilitating in situ, non-invasive measurements of large-scale net photosynthesis of benthic algae. Combined with more traditional measuring approaches this could provide an improved insight into benthic microalgal activity and the environmental controls that regulate it. The rapid developments in remote sensing of aquatic light distribution and bathymetric mapping will also facilitate more precise regional extrapolation of specific case studies in the coming years.

The sea-ice cover in the Arctic is rapidly declining (Serreze et al. 2007) and given the tight coupling between sea-ice cover and marine primary production (Rysgaard et al. 1999), this is expected to increase Arctic productivity. Arrigo et al. (2008) estimated that the pelagic productivity of the Arctic oceans has increased by $5-6 \%$ annually in recent years as a consequence of the increased light availability. Increased light availability is expected to further increase the competition for nutrients and we speculate that benthic primary production may consequently be stimulated significantly more than the pelagic production in the low-nutrient Arctic coastal region. On the other hand, a predicted increase in precipitation and permafrost thawing will increase the nutrient-enriched, turbid freshwater run-off and may locally counteract the expected increase in coastal light availability. The net outcome is hard to predict and can only be elucidated by giving priority to long-term observatory-based measurements of coastal primary production, which forms the foundation for the present and the future Arctic coastal food web.

\section{Acknowledgements}

We sincerely acknowledge Olga Kimmins for help translating the Russian literature that was made available to us. The work was supported by the Danish Natural Science Research Council, National Environmental Research Council (UK - NE/F012691/1 \& NE/F020406/1) and the Deutsche Forschungsgemeinschaft for financial support (UK899/12-1/2/3). JW and UK also thank the crew at the AWIPEV-base at Ny Ålesund (Svalbard), and the German dive team (under supervision of Max Schwanitz) for assistance in the field. We thank Dr Phil Hwang for the calculation on periods of open-water in the coastal Arctic and two anonymous reviewers for constructive criticism improving the manuscript.

\section{References}

Arrigo, K.R., G. van Dijken and S. Pabi. 2008. Impact of a shrinking Arctic ice cover on marine primary production. Geophys. Res. Lett. 35: L19603.

Badger, M.R., S. Von Caemmerer, S. Ruuska and H. Nakano. 2000. Electron flow to oxygen in higher plants and algae: rates and control of direct photoreduction (Mehler reaction) and rubisco oxygenase. Phil. Trans. Rov. Soc. B 355: 14331446.

Barranguet, C. and J. Kromkamp. 2000. Estimating production rates from photosynthetic electron transport in estuarine microphytobenthos. Mar. Ecol. Prog. Ser. 204: 39-52.

Berg, P., H. Røy, F. Janssen, V. Meyer, B.B. Jørgensen, M. Huettel and D. de Beer. 2003. Oxygen uptake by aquatic sediments measured with a novel non-invasive eddy correlation technique. Mar. Ecol. Prog. Ser. 261: 75-83.

Berg, P., H. Røy and P.L. Wiberg. 2007. Eddy correlation flux measurements - the sediment surface area that contributes to the flux. Limnol. Oceanogr. 52: 1672-1684. 
Berg, P., R.N. Glud, A. Hume, H. Stahl, K. Oguri, V. Meyer and H. Kitazato. 2009. Eddy correlation measurements of oxygen uptake in deep ocean sediments. Limnol. Oceanogr. Meth. 7: 576-584.

Blanchard, G.F. and P.A. Montagna. 1992. Photosynthetic responses of natural assemblages of marine benthic microalgae to short and long-term variations of incident irradiance in Baffin Bay, Texas. J. Phycol. 28: 7-14.

Bondarchuk, L.L. 1974. Characteristic features of the benthic diatoms in the near-shore zone of the White Sea (In Russian). In: (A.N. Golokov, ed.) Hydrobiology and biogeography of the shelf of the temperate and cold waters of the ocean. Nauka: Leningrad. pp. 93-94.

Bondarchuck, L.L. 1980. Diatoms in near-shore sediments of Kandalaksha Bay (White Sea) (In Russian). In: (Z.A. Filatova, ed.) Benthic flora and production of the marginal sea of USSR. Nauka: Moskow. pp. 63-73.

Brand, A., D.F. McGinnis, B. Wehrli and A. Wüest. 2008. Intermittent oxygen flux from the interior into the bottom boundary of lakes as observed by eddy correlation. Limnol. Oceanogr. 53: 1997-2006.

Cahoon, L.B. 1988. Use of a whirling cup rotor to stir benthic chambers. Hvdrobiologia 160: 193-198.

Cahoon, L.B. 1999. The role of benthic microalgae in neritic ecosystems. Oceanogr. Mar. Biol. Annu. Rev. 37: 47-86.

Cahoon, L.B. and J.E. Cooke. 1992. Benthic microalgal production in Onslow Bay, North Carolina, USA. Mar. Ecol. Prog. Ser. 84: 185-196.

Cammen, L. 1991. Annual bacterial production in relation to benthic microalgal production and sediment oxygen uptake in an intertidal sandflat and an intertidal mudflat. Mar. Ecol. Prog. Ser. 71: 13-25.

Charpy-Roubaud, C. and A. Sournia. 1990. The comparative estimation of phytoplanktonic, microphytobenthic and macrophytobenthic primary production in the oceans. Mar. Microb. Food Webs 4: 31-57.

Christensen, P.B., R.N. Glud, T. Dalsgaard and P. Gillespie. 2003. Implications of long line mussel farming on benthos, oxygen and nitrogen dynamics in coastal sediments. Aquaculture 218: 567-588.

Colijn, F. and V.N. de Jonge. 1984. Primary production in the Ems - Dollard Estuary. Mar. Ecol. Prog. Ser. 14: 185-196.

de Beer, D., A. Glud, E. Epping and M. Kühl. 1997. A fast responding $\mathrm{CO}_{2}$ microelectrode for profiling in sediments, microbial mats and biofilms. Limnol. Oceanogr. 42: 15901600.

Epping, E.H.G. and B.B. Jørgensen. 1996. Light enhanced oxygen respiration in benthic phototrophic communities. Mar. Ecol. Prog. Ser. 139: 193-203.

Epping, E.H.G., A. Khalili and R. Thar. 1999. Photosynthesis and dynamics of oxygen consumption in a microbial mat as calculated from transient oxygen microprofiles. Limnol. Oceanogr. 44: 1936-1948.

Eyre, B.D. and A.J.P. Ferguson. 2002. Comparison of carbon production and decomposition, benthic fluxes and denitrification in seagrass, phytoplankton, benthic microalgae- and macroalgae- dominated warm-temperate Australian lagoons. Mar. Ecol. Prog. Ser. 229: 43-59.

Fenchel, T. and R.N. Glud. 2000. Benthic primary production and $\mathrm{O}_{2}-\mathrm{CO}_{2}$ dynamics in a shallow water sediment: spatial and temporal heterogeneity. Ophelia 53: 159-171.

Gattuso, J.-P., B. Gentili, C.M. Duarte, J.A. Kleypas, J.J. Middelburg and D. Antoinne. 2006. Light availability in the coastal ocean: impact on the distribution of benthic photosynthetic organisms and their contribution to primary production. Biogeosci. 3: 489-513.

Glud, R.N. 2008. Oxygen dynamics of marine sediments. Mar. Biol. Res. 4: 243-289.

Glud, R.N., N.B. Ramsing and N.P. Revsbech. 1992. Photosynthesis and photosynthesis-coupled respiration in natural biofilms quantified with microsensors. J. Phycol. 28: 51-60.
Glud, R.N., M. Kühl, F. Wenzhoefer and S. Rysgaard. 2002. Benthic diatoms of a high Arctic fjord (Young Sound, NE Greenland): importance for ecosystem primary production. Mar. Ecol. Prog. Ser. 238: 15-29.

Glud, R.N., P. Berg, H. Fossing and B.B. Jørgensen. 2007a. Effect of the diffusive boundary layer (DBL) on the benthic mineralization and $\mathrm{O}_{2}$ distribution: a theoretical modeling exercise. Limnol. Oceanogr. 52: 547-557.

Glud, R.N., S. Rysgaard, M. Kühl and J.W. Hansen. 2007b. The sea-ice in Young Sound: implications for carbon cycling. In: (S. Rysgaard and R.N. Glud, eds) Carbon cycling in Arctic marine ecosystems: case study Young Sound. Danish Polar Center, Copenhagen. pp. 61-85.

Glud, R.N., B.D. Eyre and N. Patten. 2008. Biogeochemical responses to coral mass spawning at the Great Barrier Reef: effects on respiration and primary production. Limnol. Oceanogr. 53: 1014-1024.

Grant, J. 1986. Sensitivity of benthic community respiration and primary production to changes in temperature and light. Mar. Biol. 90: 229-306.

Hancke, K. and R.N. Glud. 2004. Temperature effects on respiration and photosynthesis in three diatom dominated benthic communities. Aquat. Microb. Ecol. 37: 265-281.

Horner, R. and G.C. Schrader. 1982. Relative contributions of ice algae, phytoplankton and benthic microalgae to primary production in near-shore regions of the Beaufort Sea. Arctic 35: 485-503.

Huettel, M. and G. Gust. 1992. Solute release mechanisms from confined cores in stirred benthic chambers and flume flows. Mar. Ecol. Prog. Ser. 82: 187-197.

Jahnke, R.A. 2005. Transport processes and organic matter cycling in coastal sediments. In: (A.R. Robinson and K.H. Brink, eds) The global coastal ocean multi scale interdisciplinary processes. Harvard University Press, Cambridge, MA. pp. 163-191.

Jahnke, R.A., J.R. Nelson, R.L. Marinelli and J.E. Eckman. 2000. Benthic flux of biogenic elements on the southeastern US continental shelf: influence of porewater advective transport and benthic microalgae. Cont. Shelf Res. 20: 109-127.

Jakobsson, M.R., R. Macnab, L. Mayer, R. Andersson, M. Edwards, J. Hatzky, H.W. Schenke and P. Johnson. 2008. An improved bathymetric portrayal of the Arctic Ocean: implications for ocean modeling and geological, geophysical and oceanographic analysis. Geophys. Res. Lett. 7: L07602.

Jerlov, N.G. 1970. Light. In: (O. Kinne, ed.) Marine ecology. Wiley Interscience: London. pp. 95-102.

Jönsson, B. 1991. A C ${ }^{14}$ incubation technique for measuring microphytobenthic primary productivity in intact sediment cores. Limnol. Oceanogr. 36: 1485-1492.

Jørgensen, B.B. and D.J. des Marais. 1990. The diffusive boundary layer of sediments: oxygen microgradients over a microbial mat. Limnol. Oceanogr. 35: 1343-1355.

Karsten, U., R. Schumann, S. Rothe, I. Jung and L. Medlin. 2006. Temperature and light requirements for growth of two diatom species (Bacillariophyceae) isolated from an Arctic macroalga. Polar Biol. 29: 476-486.

Krause-Jensen, D., M. Kühl, P.B. Christensen and J. Borum. 2007. Benthic primary production in Young Sound, Northeast Greenland. In: (S. Rysgaard and R.N. Glud, eds) Carbon cycling in Arctic marine ecosystems: case study Young Sound. Danish Polar Center, Copenhagen. pp. 159-173.

Kühl, M. 2005. Optical microsensors for analysis of microbial communities. Meth. Enzymol. 397: 166-199.

Kühl, M., R.N. Glud, H. Ploug and N.B. Ramsing. 1996. Microenvironmental control of photosynthesis and photosynthesiscoupled respiration in an epilithic cyanobacterial biofilm. $\mathbf{J}$. Phycol. 32: 799-812.

Kühl, M., C. Lassen and N.P. Revsbech. 1997. A simple light meter for measurements of PAR $(400-700 \mathrm{~nm})$ with fiberoptic microprobes: application for $\mathrm{P}$ vs. I measurements in microbenthic communities. Aquat. Microb. Ecol. 13: 197207. 
Kühl, M., R.N. Glud, J. Borum, R. Roberts and S. Rysgaard. 2001. Photosynthetic performance of surface-associated algae below sea ice as measured with a pulse-amplitudemodulated (PAM) fluorometer and $\mathrm{O}_{2}$ microsensors. Mar. Ecol. Prog. Ser. 223: 1-14.

Kuwae, T., K. Kamio, T. Inoue, E. Miyoshi and Y. Uchiyama. 2006. Oxygen exchange flux between sediment and water in an intertidal sandflat, measured in situ by the eddy-correlation method. Mar. Ecol. Prog. Ser. 307: 59-68.

Kuznetsov, L.L. 1991. Microphytobenthos production in the Barents Sea coastal zone. In: (G.G. Matishoc, ed.) Production-destruction processes in the Barents sea coastal zone. KNC RAN: Apatity. pp. 52-62. (in Russian).

Kuznetsov, L.L. 2002. Production of phytocoenoses and transformation of nutrients in ecosystem of the Barents Sea (in Russian) Abstract of thesis of doctor of biology. Shirshov Institute of Oceanology, Moscow.

Kuznetsov, L.L. 2005. Comparative characteristics of phytocoenoses production in the Barents Sea. In: (V. Shibanov, ed.) Ecosystem dynamics and optimal long-term harvest in the Barents Sea fisheries. PINRO, Murmansk. pp. 228-232.

Kuznetsov, L.L. and T.L. Strogaya. 1989. Microphytobenthos production indices and oxygen uptake by the community of the Dalnezelenetskaya Bay littoral (Barents Sea) - (in Russian). Hirobiologicheskii Zhurnal 25: 104-106.

Kuznetsov, L.L, O.N. Baytaz and P.R. Makarevich. 1998. Structural-functional characteristics of the plankton community in the Baidara bay on materials of expeditions in autmn 1991-1992. In: Biology and oceanography of the Kara and Barents Seas (along the Arctic seaway route). KNC RAN. Apatity. pp. 88-95. (in Russian).

Larkum, A.W.D., E.M. Koch and M. Kühl. 2003. Diffusive boundary layers and photosynthesis of the epilithic algal community of coral reefs. Mar. Biol. 142: 1073-1082.

Lassen, C., R.N. Glud, N.B. Ramsing, N.P. Revsbech. 1998. A method to improve the spatial resolution of photosynthetic rates obtained by oxygen microsensors. J.Phycol. 34: 83-93.

Longphuirt, S.N., J. Clavier, J. Grall, L. Chauvaud, F. le Loc'h, I. le Berre, J. Flye-Sainte-Marie, J. Richard and A. Leynaert. 2007. Primary production and spatial distribution of subtidal microphytobenthos in a temperate coastal system, the Bay of Brest, France. Estuar. Coast. Shelf Sci. 74: 367-380.

Maclntyre, H.L., R.J. Geider and D.C. Miller. 1996. Microphytobenthic: the ecological role of the "secret garden" of unvegetated, shallow-water marine habitats. I. Distribution, abundance and primary production. Estuar. Coasts 19: 186201.

Matheke, G.E.M. and R. Horner. 1974. Primary productivity of the benthic microalgae in the Chukchi Sea near Barrow, Alaska. J. Fish Res. Board Can. 31: 1779-1786.

McGee, D., R.A. Laws and L.B. Cahoon. 2008. Live benthic diatoms from the upper continental slope: extending the limits of marine primary production. Mar. Ecol. Prog. Ser. 356: 103-112.

McMinn, A., T. Hirawake, T. Hamaoka, H. Hattori and M. Fukuchi. 2005. Contribution of benthic microalgae to ice covered coastal ecosystems in northern Hokkaido, Japan. J. Mar. Biol. Ass. U.K. 85: 283-289.

Menarad, H. and S.M. Smith. 1966. Hypsometry of ocean basin provinces. J. Geophys. Res. 71: 4305-4325.

Meyercordt, J., S. Gerbersdorf and L.-A. Meyer-Reil. 1999. Significance of pelagic and benthic primary production in two shallow coastal lagoons of different degree of eutrophication in the southern Baltic Sea. Aquat. Microb. Ecol. 20: 273-284.

Middelburg, J.J., C. Barranguet, H.T.S. Bushker, P.M.J. Herman and T. Moens. 2000. The fate of intertidal microphytobenthos carbon: an in situ ${ }^{13} \mathrm{C}$ labeling study. Limnol. Oceanogr. 45: 1224-1234.

Morel, A. and L. Prieur. 1977. Analysis of variations in ocean color. Limnol. Oceanogr. 22: 709-722.
Nelson, J.R., J.E. Eckman, C.Y. Robertson, R.L. Marinelli and R.A. Jahnke. 1999. Benthic microalgae biomass and irradiance at the sea floor on the continental shelf of the South Atlantic Bight: spatial and temporal variability and storm effects. Cont. Shelf Res. 19: 477-505.

Pabi, S., G.L. van Dijken and K.R. Arrigo. 2008. Primary production in the Arctic ocean 1998-2006. J. Geophys. Res. 113: C08005.

Palmisano, A.C., J.B. Soohoo, D.C. White, G.A. Smith, G.A. Stanton and G.R. Burckle. 1985. Shade adapted benthic diatoms beneath Antarctic sea ice. J. Phycol. 21: 664-667.

Pamatmat, M.M. and D. Fenton. 1968. An instrument for measuring subtidal benthic metabolism in situ. Limnol. Oceanogr. 13: 357-540.

Parsons, T.R., D.G. Webb, H. Dovey, R. Haigh, M. Lawrence and G.E. Hopky. 1988. Production studies in the Mackenzie River - Beaufort Sea estuary. Polar Biol. 8: 235-239.

Platt, T., C.L. Gallegos and W.G. Harrison. 1980. Photoinhibition of photosynthesis in natural assemblages of marine phytoplankton. J. Mar. Res. 38: 687-701.

Rachold, V., H. Eicken, V.V. Gordeev, M.N. Grigoriev, H.-W. Hubberten, A.P. Lisitzin, V.P. Shevchenko, L. Schirrmeister. 2004. Modern terrigenous organic carbon input to the Arctic Ocean In: (R. Stein and Macdonald, eds). The organic carbon cycle in the Arctic Ocean. Springer-Verlag, Berlin. pp. 33-55.

Raven, J.A. and J. Beardall. 1981. Respiration and photorespiration. In: (T. Platt, ed.) physiological bases and phytoplankton ecology. Can. Bull. Fish. Aquat. Sci. 210: 55-82.

Revsbech, N.P. and B.B. Jørgensen. 1983. Photosynthesis of benthic microflora measured with high spatial resolution by the oxygen microprofile method: capabilities and limitations of the method. Limnol. Oceanogr. 28: 749-756.

Revsbech, N.P., B.B. Jørgensen and O. Brix. 1981. Primary production of microalgae in sediments measured by oxygen microprofile, $\mathrm{H}^{14} \mathrm{CO}_{3}^{-}$fixation, and oxygen exchange methods. Limnol. Oceanogr. 26: 717-730.

Rosenberg, R. and L. Lundberg. 2004. Photoperiodic activity pattern in the brittle star Amphiura filiformis. Mar. Biol. 145: 651-656.

Rysgaard, S., T.G. Nielsen and B. Hansen. 1999. Seasonal variation in nutrients, pelagic primary production and grazing in a high-arctic coastal marine ecosystem, Young Sound, NEGreenland. Mar. Ecol. Prog. Ser. 179: 13-25.

Schreiber U. 2005. Pulse-amplitude (PAM) fluorometry and saturation pulse method. In: (Papageorgiou G, Govindjee, eds) Chlorophyll fluorescence: a signature of photosynthesis. Advances in photosynthesis and respiration series, Vol. 19. Kluwer Academic Publishers, Dordrecht. pp. 279-319.

Serreze, M.C., M.M. Holland and J. Stroeve. 2007. Perspectives on the Arctic's shrinking sea-ice cover. Science 315: $1533-1536$.

Springer, A.M. and C.P. McRoy. 1993. The paradox of pelagic food webs in the northern Bering Sea-III. Patterns of primary production. Cont. Shelf Res. 5-6: 575-599.

Steenmann-Nielsen, E. 1952. The use of radio-active carbon $\left({ }^{14} \mathrm{C}\right)$ for measuring organic production in the sea. $J . d u$ Conseil Expl. M. 18: 117-140.

Subba-Rao, D.V. and T. Platt. 1984. Primary production of Arctic waters. Polar Biol. 3: 191-201.

Sun, M.Y., R.C. Aller and C. Lee. 1994. Spatial and temporal distributions of sedimentary chloropigments as indicators of benthic processes in Long Island Sound. J. Mar. Res. 52: 149-176

Taddei D., P. Cuet, P. Frouin, C. Esbelin and J. Clavier. 2008 Low community photosynthetic quotient in coral reef sediments. Comp. Rendus Biologies 9: 668-677.

Tengberg, A., P.O.J. Hall, U. Andersson, B. Lidén, O. Styrenius, G. Boland, F. de Bovee, B. Carlsson, S. Ceradini, A. Devol, G. Duineveld, J.U. Friemann, R.N. Glud, A. Khripounoff, J. Leather, P. Linke, L. Lund-Hansen, G. Rowe, P. Santschi, P. de Wilde and U. Witte. 2005. Intercalibration of benthic flux 
chambers II. Hydrodynamic characterization and flux comparison of 14 different designs. Mar. Chem. 94: 147-173.

Vetrov, A.A. and E.A. Romankevich. 2004. Carbon cycle in the Russians Seas. Springer, Berlin. pp. 335.

Wagner, H., T. Jakob and C. Wilhelm. 2006. Balancing the energy flow from captured light to biomass under fluctuating light conditions. New Phytol. 169: 95-108.

Wenzhöfer, F. and R.N. Glud. 2004. Small-scale spatial and temporal variability in benthic $\mathrm{O}_{2}$ dynamics of coastal sediments: Impact of fauna activity. Limnol. Oceanogr. 49: 1471-1481.
Wenzhöfer, F., O. Holby, R.N. Glud, H.K. Nielsen and J.K. Gundersen. 2000. In situ microsensor studies of a hydrothermal vent at Milos (Greece). Mar. Chem. 69: 43-54.

Zacher, K., R. Rautenberger, D. Hanelt, A. Wulff and C. Wiencke. 2009. The abiotic environment of polar marine benthic algae. Bot. Mar. 52: 483-490.

Received 23 February, 2009; accepted 8 June, 2009; online first 30 October, 2009 